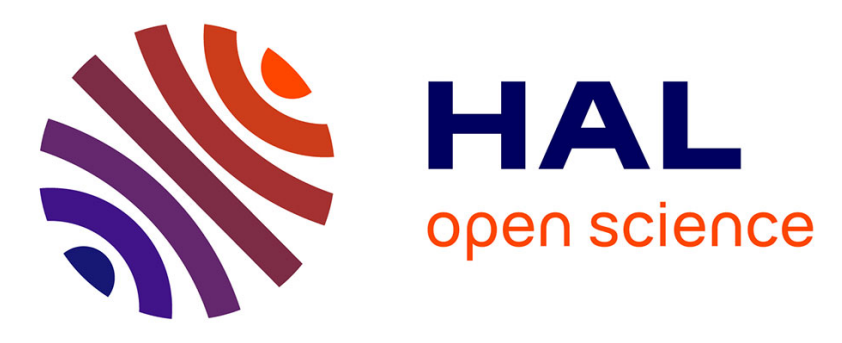

\title{
Novel electrochemical cell designed for operando techniques and impedance studies
}

\author{
Claire Villevieille, T. Sasaki, P. Novák
}

\section{To cite this version:}

Claire Villevieille, T. Sasaki, P. Novák. Novel electrochemical cell designed for operando techniques and impedance studies. RSC Advances, 2014, 4 (13), pp.6782 - 1-4. 10.1039/C3RA46184J . hal02613892

\section{HAL Id: hal-02613892 \\ https://hal.science/hal-02613892}

Submitted on 20 May 2020

HAL is a multi-disciplinary open access archive for the deposit and dissemination of scientific research documents, whether they are published or not. The documents may come from teaching and research institutions in France or abroad, or from public or private research centers.
L'archive ouverte pluridisciplinaire HAL, est destinée au dépôt et à la diffusion de documents scientifiques de niveau recherche, publiés ou non, émanant des établissements d'enseignement et de recherche français ou étrangers, des laboratoires publics ou privés. 


\title{
Novel electrochemical cell designed for operando techniques and impedance studies
}

\author{
C. Villevieille, ${ }^{* a}$ T. Sasaki ${ }^{a b}$ and P. Novák ${ }^{a}$
}

A novel electrochemical cell has been designed for operando experiments at synchrotron facilities and in house. The cell can be adapted to the most common techniques such as X-ray diffraction, X-ray absorption spectroscopy, neutron diffraction as well as electrochemical impedance spectroscopy. It allows the investigation of host materials with insertion and/or conversion reactions under high current densities, high and low temperature and pressure. We are, with this cell, able to study advanced and complex systems with a high precision and quality. The stability and advantage of the cells were demonstrated by in situ synchrotron X-ray diffraction and electrochemical impedance spectroscopy using different systems such as $\mathrm{Li}(\mathrm{Ni}, \mathrm{Co}, \mathrm{Mn}) \mathrm{O}_{2}, \mathrm{LiFePO}_{4}$ or $\mathrm{Li}(\mathrm{Ni}, \mathrm{Co}, \mathrm{Al}) \mathrm{O}_{2}$.

Received 28th October 2013 Accepted 24th December 2013

DOI: $10.1039 / c 3 r a 46184 j$

www.rsc.org/advances crystal structural changes the main characterizations is obviously the XRD investigations. They can be performed both in house with a standard laboratory diffractometer or in synchrotron source facilities. The latter will allow fast measurements with high resolution and qualities. ${ }^{16}$ For other characterizations such as XAS, synchrotron facilities are needed but especially for the short acquisition time. The possibility of using very short acquisition times, typically on the order of a few seconds for both XRD and XAS, indeed permits to investigate structural and electronic properties of electrodes out of equilibrium.

In this paper, we report the development of a novel, reliable electrochemical cell with design allowing arbitrary dimensions, to be used in transmission or in reflection mode on different beamline as well as in house measurement. This cell presents the main advantages (i) to provide a homogeneous pressure equivalent to the one we have in standard coin cell, (ii) to have high stability for cycling and storage, (iii) to avoid problems of moisture and/or air exposure, (iv) to cycle with a low quantity of materials less than $20 \mathrm{mg}$, (v) to be adapted in different beamlines, (vi) to have a flexible configuration which allows to select the most appropriate material for windows among different metal foils such as beryllium, titanium or aluminium depending of the cycling voltage of the study and (vii) to fit in our sample changer developed to run up than 34 cells at the same time in the MS powder beamline at Swiss Light Source (SLS). Other cell design were already described in the literature but to the best of our knowledge none of them are as flexible as the design of this new cell, especially the option to use a suitable, removable and transparent window, and, capable to be adapted to diverse beamlines and/or in house equipments. For this study we were using the beamline MS powder X04SA at PSI as well as the beamline Super-XAS for the X-ray diffraction and $\mathrm{X}$-absorption respectively, in order to benefit from short measurement time and to reveal the difference between 
classical "coffee bag" cell and the new design. $\mathrm{Li}(\mathrm{Ni}, \mathrm{Co}, \mathrm{Mn}) \mathrm{O}_{2}$ (NMC), $\mathrm{LiFePO}_{4}$ (LFP) or $\mathrm{Li}(\mathrm{Ni}, \mathrm{Co}, \mathrm{Al}) \mathrm{O}_{2}$ (NCA) electrode materials are used to demonstrate the concept of this novel reliable cell designed for operando measurement with synchrotron radiation. The main objectives of this study are to develop and demonstrate a reliable and flexible electrochemical cell for operando experiments adaptable to synchrotron beamlines as well as to in house devices due to the flexible design of the coffee bags cells, a design able to adapt for reflection and/or transmission geometry. The second part of the manuscript is dedicated to electrochemical impedance spectroscopy measurements performed with this new cell design and to a 4 electrodes design, to demonstrate the feasibility of the concept but mainly to show the impact of the spring and pressure on the internal resistance of the electrode mass during cycling.

\section{Experimental part}

The 'coffee bag' electrochemical cells consist of several flat parts assembled in order to have a thickness of $1 \mathrm{~mm}$ maximum. The goal is to minimize the presence of the different element inside the batteries such as the current collector and to maximize the presence of electroactive element in the beam. Fig. 1 presents a schematic drawing of the conventional "coffee bag" cell. Due to the high reactivity of the lithium with air and moisture, "coffee bag" cell must be air and moisture tight, which represents a challenge for a "coffee bag" cell. For this reason the cells are sealed in an aluminium bag ( $100 \mu \mathrm{m}$-thick) where the foil is composed by four layers: from the inside to the outside (i) polyethylene (PE), (ii) aluminium, (iii) PE and (iv) oriented polyamide (OPA). The PE layer is thermosealable while the OPA layer is not, thus being on the outside of the cell. The $25 \mu \mathrm{m}$ thick aluminium layer is a perfect and necessary barrier to $\mathrm{O}_{2}$ and $\mathrm{H}_{2} \mathrm{O}$. The only problem of such a composite foil is that this introduces additional peaks in the XRD patterns.

As seen in Fig. 1, and, in order to avoid this problem a hole was done in the "coffee bag" cell and the aluminium was

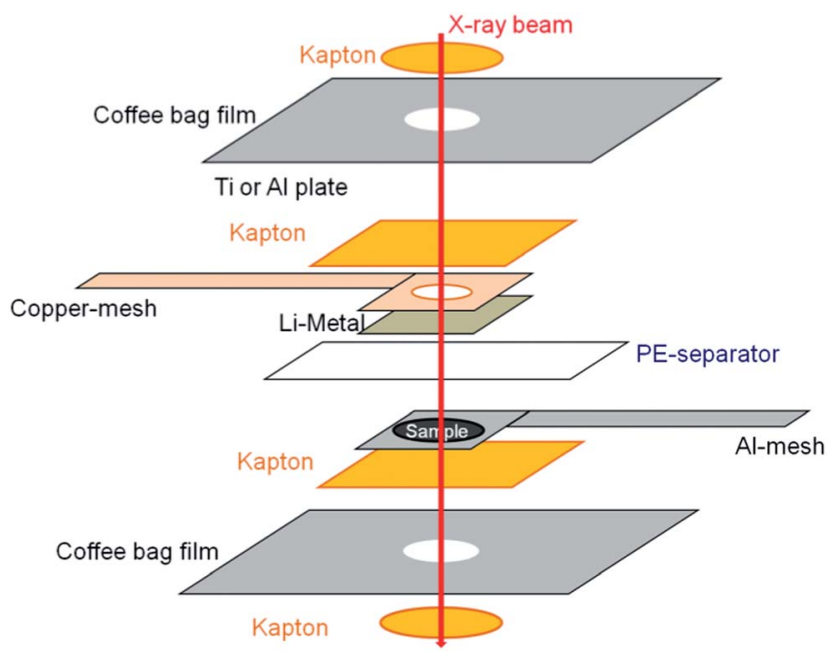

Fig. 1 Conventional "coffee bag" cell. replaced by some Kapton tape to avoid any Bragg reflection from the window. Then in order to avoid also the reflection coming from the current collector, copper and/or aluminium mesh were used. The electrodes were prepared by the common 'doctor blade' technique which consists of spreading a slurry in organic solvent NMP ( $N$-Methyl-2-pyrrolidone) of the electroactive material $(70 \% \mathrm{wt})$, a conductive additive (graphite and/or carbon black) (10\% wt) and a binder PVDF (Polyvinylidene fluoride) $(20 \% \mathrm{wt})$. The slurry is first spread onto a non-adhesive sheet from which it is easily removed once dried. The freestanding electrodes $(2 \mathrm{~cm} \times 2 \mathrm{~cm})$ are cut with a scalpel and then pressed on the respective mesh current collectors. All cell components are then dried in vacuum at $393 \mathrm{~K}$ overnight to remove all traces of solvents and humidity and subsequently transferred into an Ar-filled glove box. Inside the glove box, the cells are assembled, filled with the electrolyte, $1 \mathrm{M}$ of $\mathrm{LiPF}_{6}$ in a $1: 1 \mathrm{wt} \%$ mixture of ethylene carbonate (EC) and dimethyl carbonate (DMC), and then sealed. A PE separator (Tonen Chemical, E25MMS, $25 \mu \mathrm{m}$ of thickness) was then chosen because of its low thickness, good electrochemical performance and good wettability towards the electrolyte. The "coffee bag" cell as described in Fig. 1 is called conventional "coffee bag" but it presents many disadvantages like (i) the Kapton windows are a good barrier to prevent the oxygen leakage but it is rather not a good barrier to avoid moisture, (ii) due to the softness of Kapton windows, it is impossible to apply an homogeneous pressure from the inside or from the outside, the Kapton tape is not hard enough and will make a flexure when applying pressure and (iii) the glue of the Kapton tape can react with the electrolyte and create a polymer which leads to the degradation of the electrolyte properties.

In the literature, other research groups decided to change the settings of "coffee bag" by using the cells available on the market such as the real coin cell or Swagelok@ cell. ${ }^{17}$ For the best of our knowledge none of these options is really appropriate for a compromise of good electrochemistry and good data quality, because of, firstly, the use of the coin cell with a full settings leads to lots of parasite peaks in the XRD patterns (or XAS spectra), secondly, the second settings which consist of a half Swagelok@ cell with beryllium windows, is a good settings to avoid air exposure and moisture but the three main problems are (i) using beryllium windows practically transparent to X-rays leads to major health concerns due to its toxicity, (ii) corrosion of beryllium occurs while cycling at potential positive to $3.5 \mathrm{~V} v s$. $\mathrm{Li}^{+} / \mathrm{Li}$ (so studies of positive electrode are not suitable or and additional aluminium film is needed to prevent the corrosion of the beryllium) and, (iii) even if the cell possesses a spring inside able to apply a pressure, beryllium is a really fragile material and in such a case no pressure can be apply on the window without breaking it or twisting it. In the last case, if the beryllium breaks, this will lead to air exposure and moisture on the electrode material, which then, affected the electrochemical properties and leads to failure of the cell. The key issue is that the electrochemical behaviour is not the one expected from the real electrochemistry found in standard commercial cell without any pressure inside the cell. In such a case a lot of studies have reported heterogeneous reactions while cycling 
with "coffee bag" cells, but without any pressure this behaviour is extrapolated and can come only from the settings properties. Due to lack of a good and reliable cell with pressure dedicated to operando studies, we decided to modify the standard "coffee bag" cell to improve the pressure coming from the spring in order to obtain similar results than those obtained by coin cell measurement. At the same time, we will keep the main advantages of "coffee bag" such as adaptability to all the possible settings and beamline.

We then have developed a new setting keeping the basis of a "coffee bag" cell, which is the most suitable to adapt to all the beamline and all the experiments, and we found a way to suppress the problem of Kapton window by using different materials for the construction which assume multiple roles as the window and also the current collector (Fig. 2). In such a case we were able to limit the number of different materials in the beam. For our approach, 2 different windows were used, aluminium or titanium. In both cases the windows were sealed directly to the "coffee bag" cell by using a double layer of parafilm films (Parafilm; Pechiney Plastic Packaging Company), used here as a polymer to melt directly on the PE of the "coffee bag" cell and on the window. In such a way, the titanium or aluminium windows are directly linked to the coffee bag but with this approach we were not able to have a perfect isolation against air and moisture due to the fact that parafilm is not water proof. Thus, this problem was solved by using a Kapton tape (see Fig. 2). In such a case the melted parafilm is then protected by another Kapton barrier. A water proof test was then performed in our lab, in which metallic lithium was placed inside the new "coffee bag" cell and the cell was immersed in water for 3 weeks. After 3 weeks the cell was disassemble and examined, an, the lithium was shiny without any visible trace of oxidation and hydroxylation. To avoid additional peak in the spectra, we removed the inside part of the Kapton in order to cover only the sealing part. The working electrodes were prepared by casting the slurry, composed of active materials powders, conductive carbon (TIMCAL Super-P), and (PVDF; Solev 6020, Solvay SA) in the (NMP) solvent, directly on the window films (titanium or aluminium for the study) to eliminate the contribution of other element in the beam.

A double polypropylene (PP) layer was also added in the four edges of the coffee bag cells. This PP plays a double role, first of all to create a better sealing interface between the titanium or aluminium foil and the aluminium bag, to avoid short circuit in case of too strong heating during the sealing step and, to prevent air exposure.

The main goal of using a "hard" window such as titanium is that its mechanical strength is high enough to support a high pressure coming from the spring, and then to apply a real pressure inside the coffee bag cells, a goal never reached in the other cells in the previous studies. No pressure can be applied with the beryllium due to the weakness of the beryllium, and in others full cell, we can apply a pressure but we have many other components in the beam. In this study, the pressure is applied from outside by applying a wave spring (similar to the spring used in real commercial coin cells) on the top of the window. The spring is then pressed on the "coffee bag" windows when we close the casing used for the measurement.
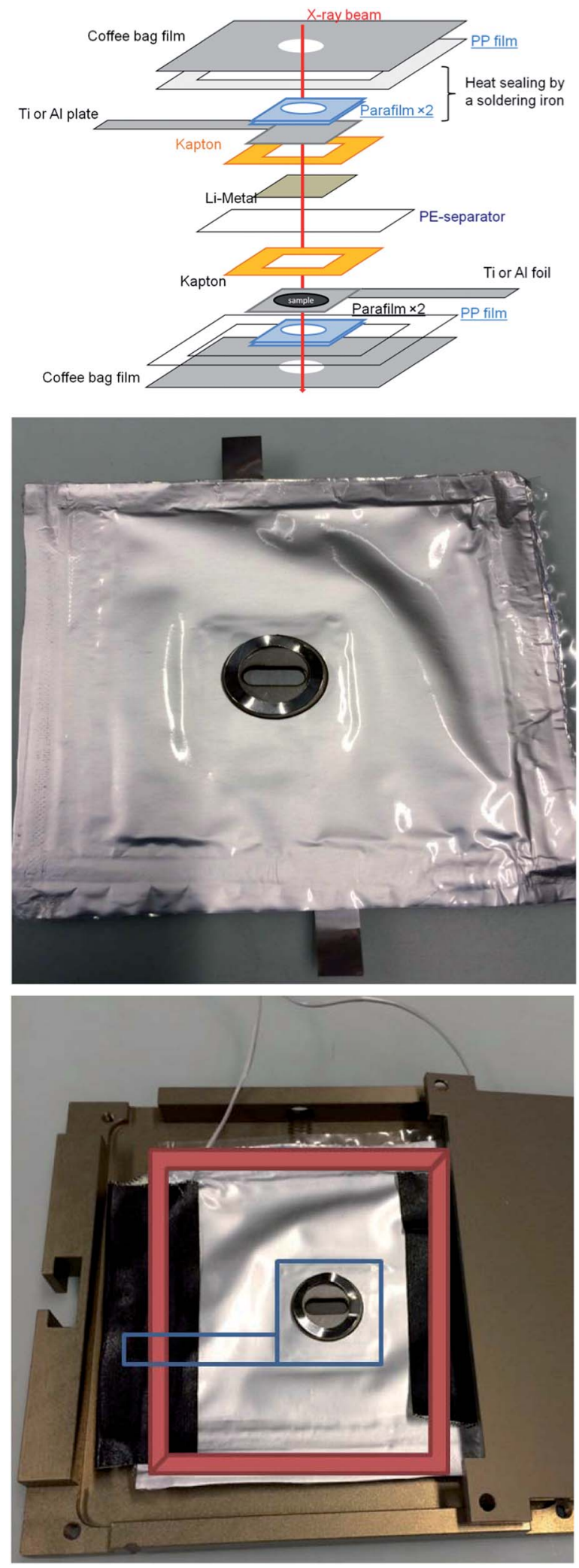

Fig. 2 (Top) Modified "coffee bag" cell design, (middle) photograph of the modified "coffee bag" cell with the spring, (bottom) modified "coffee bag" cell in the casing prior to the measurement at the beamline, in red the sealed edges, and in blue, the position of the titanium windows/current collector with the spring on top. 


\section{Results and discussions}

In order to prove the concept of this modified "coffee bag" cell using titanium windows and pressure applied thanks to a wave spring has exactly the same properties of standard cells, we compared the charge-discharge curves between the "coffee bag" cell and the standard coin-type cell with $\mathrm{LiFePO}_{4}$ at $\mathrm{C} / 4$ rate. As we can see in Fig. 3a, there is no clearly visible difference between the "coffee bag" cell and the standard coin-type cell at relative fast rate. Then, the biphasic plateau is located exactly between $3.4 \mathrm{~V}$ and $3.55 \mathrm{~V} v s$. $\mathrm{Li}^{+} / \mathrm{Li}$, like described in the literature. If we have a closer look now on the polarization between the two different cells, Fig. 3b, we can see an increase of the polarization for the "coffee bag" cell as a comparison with the standard cell. On delithiation, the difference between the standard cell and the "coffee bag" cell is less than $10 \mathrm{mV}$ and on lithiation the difference is close to $20 \mathrm{mV}$. This difference is considered as negligible for this kind of study, especially as $\mathrm{C} / 4$ rate.

We also evaluated the stability of this modified "coffee bag" cell by charge-discharge cycling tests. It took about 3 weeks in the air and moisture atmosphere. First of all, as we can see in Fig. 4, no oxidation or fading is observed on the modified "coffee bag" cell, which means that there is no deterioration of the lithium and/or electrolyte (normally observed in classical "coffee bags"). After 36 cycles, the polarisation was almost the same between the second and the thirty-sixth cycle. The end of
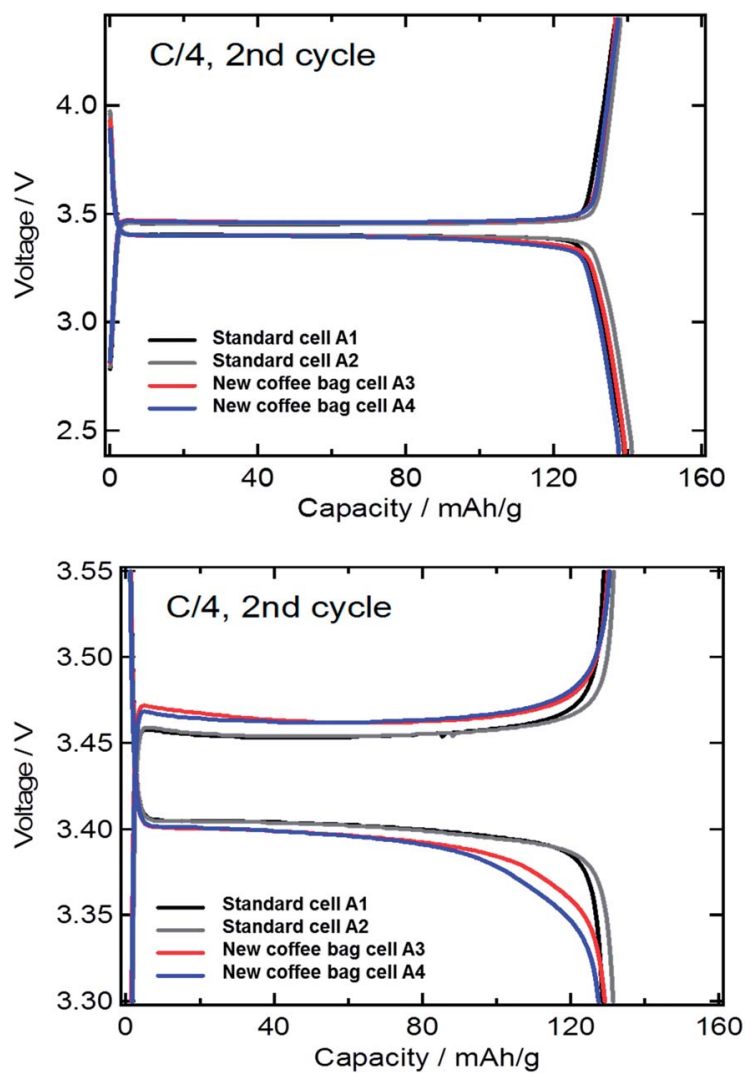

Fig. 3 Galvanostatic curves of $\mathrm{LiFePO}_{4}$ in a standard coin-type cell and "coffee bag" cell (top) full scale, (bottom) enlargement. charge and discharge curve of the "coffee bag" cell showed slightly larger polarisation than that of the standard cell supposedly due to the degradation of the active materials. Concerning the specific charge, the difference between the cell with pressure and the cell without pressure is about $2-3 \%$ which can be considered as negligible under normal experimental condition.

The same evaluation was made in the full range of potential from the graphite electrode to the high voltage NMC (named HENMC). The same cycling program was applied for both systems. In the case of the cell without pressure a potentiostatic step at the end of the delithiation process is visible. This potentiostatic step was set as both time limitation and current density limitation, in the case of the cell with pressure, the current density limitation was reached immediately that's why no potentiostatic plateau appears on the curves. In the case of the non-pressure cell, the equilibrium was not reached as fast as with the cell with pressure, especially for the first and second cycle, and one can see this plateau in the galvanostatic curves (Fig. 5), indicating once again the crucial role of pressure inside the cell.

In the case of no pressure, the electrochemistry is totally different, that is, a huge polarization and a decrease in specific charge of minimum $10 \%$ is observed (for a better visibility we normalized the curves in Fig. 6). In Fig. 5 we can see the effect of the pressure on HE-NMC materials for the 2nd and 50th (after more than 1 month). The results obtained in the modified "coffee bags" are perfectly matching the results obtained in classical coin cell. There is no overpotential observed as well as no new phenomena and the specific charge is clearly similar.

In Fig. 6, we can see the difference between the modified "coffee bag" with pressure and another one without any pressure. Already for the second cycle, we can see a large difference between the modified "coffee bag" with pressure in comparison with the one without pressure. A decrease in specific charge of more than $10 \%$ was observed just after two cycles in the "coffee bag" without pressure. After 50 cycles (Fig. 6 bottom) (for the "coffee bag" cells which "survive" outside during one month

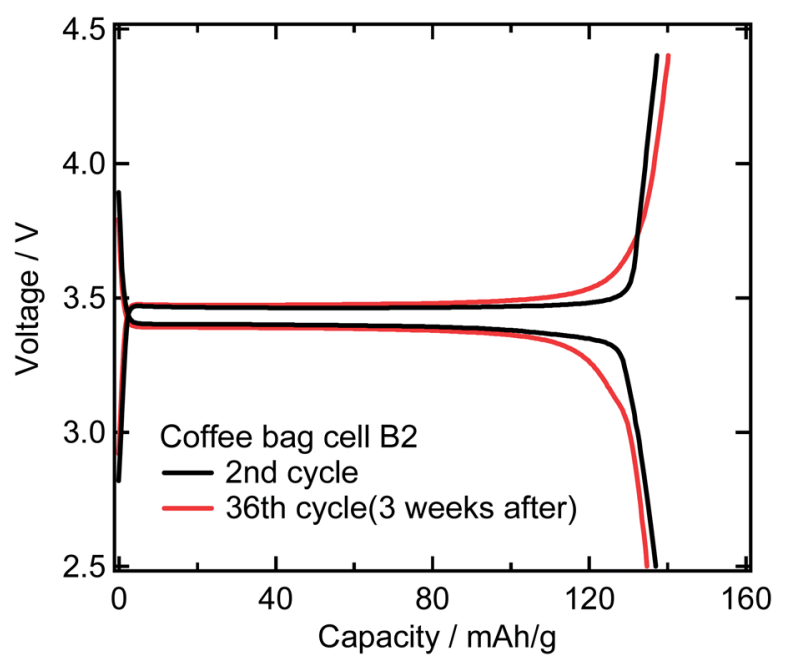

Fig. 4 Comparison of charge-discharge curves between the 2 nd and the 36th cycle of the "coffee bag" cell with pressure. 

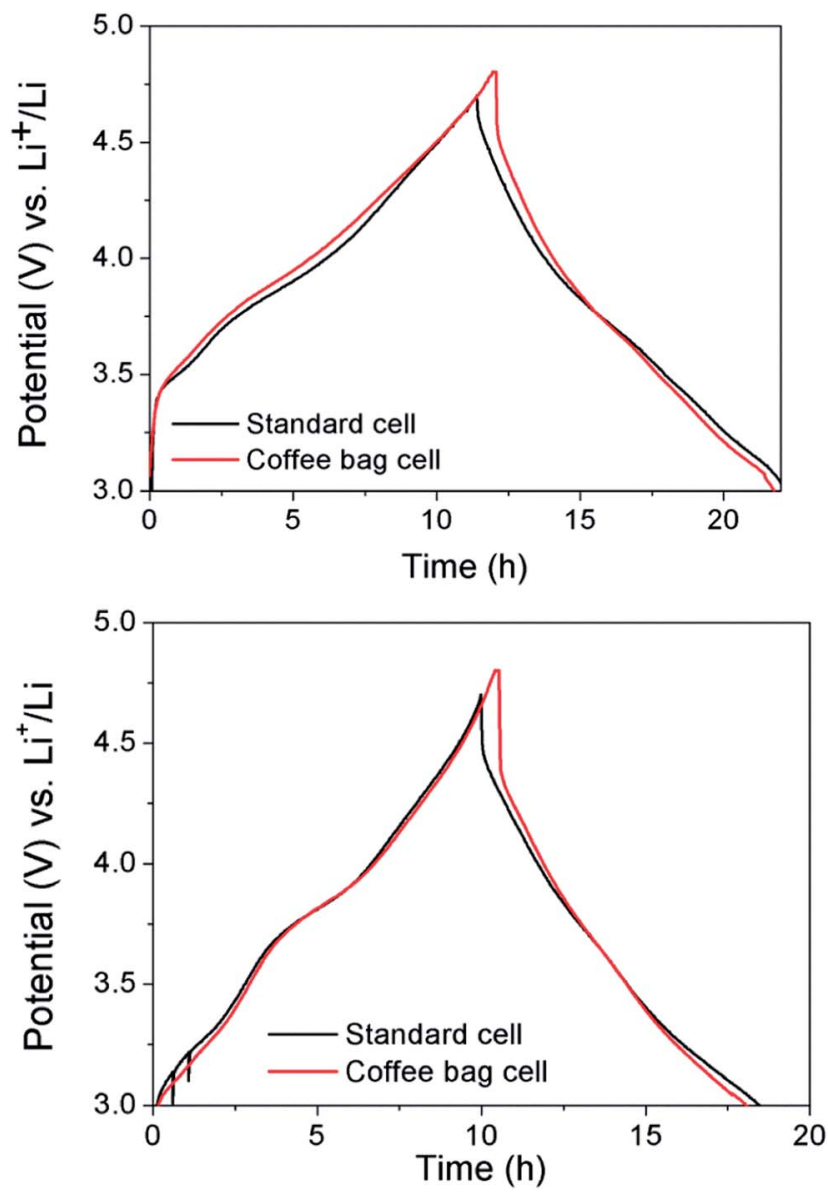

Fig. 5 Galvanostatic curves of HE-NMC for a standard cell and modified "coffee bag" cell with pressure between 3 and $5 \mathrm{Vvs}$. $\mathrm{Li}^{+} / \mathrm{Li}$, (top) for the 2 nd cycle (bottom) for the 50 th cycle.

that is mean less than $20 \%$ of them), we see now a big difference between the two curves, the polarization is bigger, then there is still less specific charge, and the difference phenomena are totally decay in potential as a comparison with the standard one with pressure.

This instability is one of the typical disadvantages of the "coffee bag" cell without pressure. It is then almost impossible to trust the results during cycling especially for long term measurements. In order to confirm this problem we measured operando synchrotron X-ray diffraction of HE-NMC in the "coffee bag" cell without pressure and with pressure after 2 cycles and 50 cycles, as shown in Fig. 7 and 8, respectively. First of all, we can notice the most intense peak in Fig. 8 at $16.45^{\circ}$ ascribable to the titanium (windows) coming from the new configuration of the modified "coffee bag". This peak is not appearing in the Fig. 7 because the configuration of the "coffee bag" was the old one with Kapton window.

Then if we have a closer look on the reaction of the HE-NMC after 50 cycles cycled in the "coffee bag" cell with and without pressure, we can see the same trend.

Fig. 7 and 8 suggest that a solid solution reaction occurs during the first electrochemical process, in which the starting phase is delithiated and transforms into another phase with
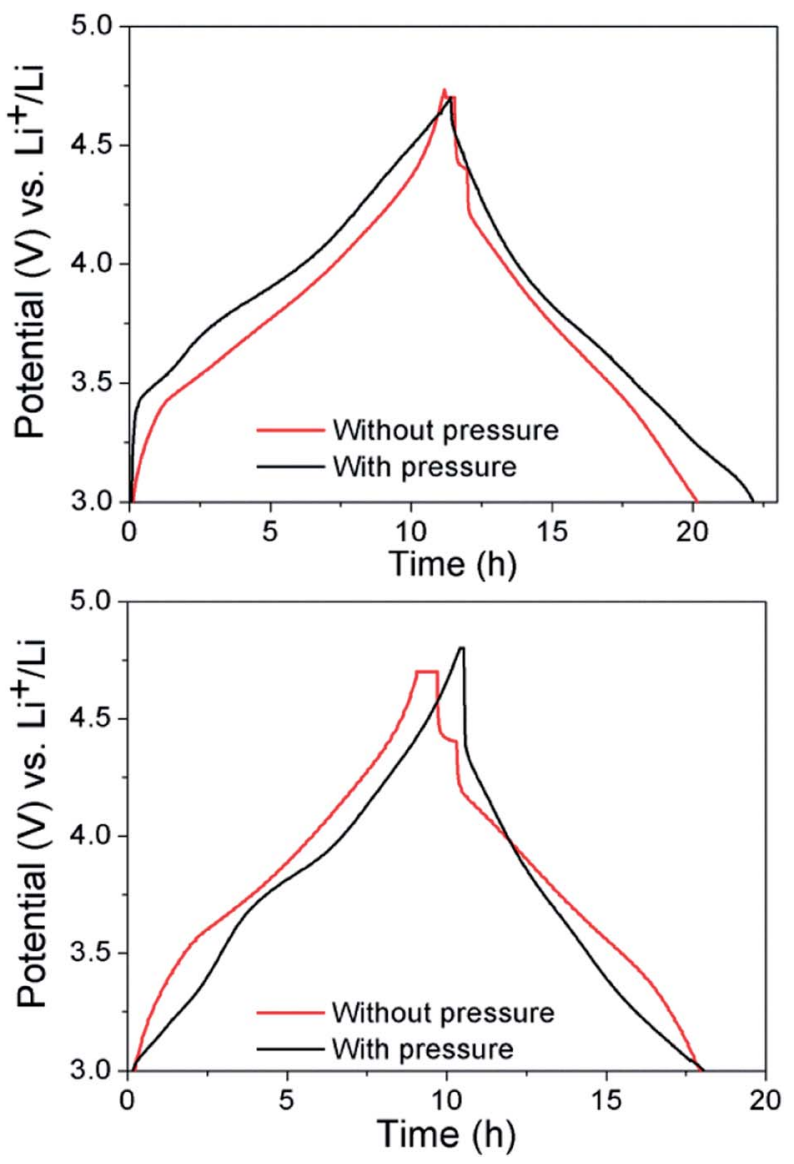

Fig. 6 Galvanostatic curves of HE-NMC for a "coffee bag" cell without pressure and "coffee bag" cell with pressure between 3 and $5 \mathrm{~V} \mathrm{vs.} \mathrm{Li}^{+} /$ $\mathrm{Li}$, (top) for the 2nd cycle (bottom) for the 50th cycle.

different cell parameters. The mechanism was already described in the literature by Tran et al. ${ }^{18}$ Fig. 7 and 8 show a shift of the HE-NMC-phase to higher $2 \theta$-angles during delithiation. This shift corresponds to a decrease in the $c$ lattice parameter and an increase in the $a$ lattice parameter. In both

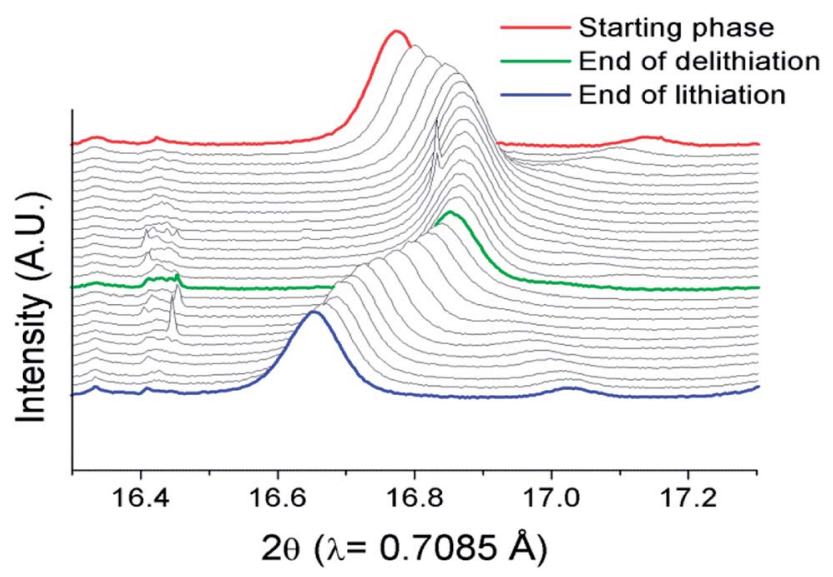

Fig. 7 Operando synchrotron XRD pattern of HE-NMC after 50 cycles in a "coffee bag" cell at C/10 between $2.5 \mathrm{~V}$ and $4.8 \mathrm{~V} \mathrm{vs}$. $\mathrm{Li}^{+} / \mathrm{Li}$ without any pressure. 


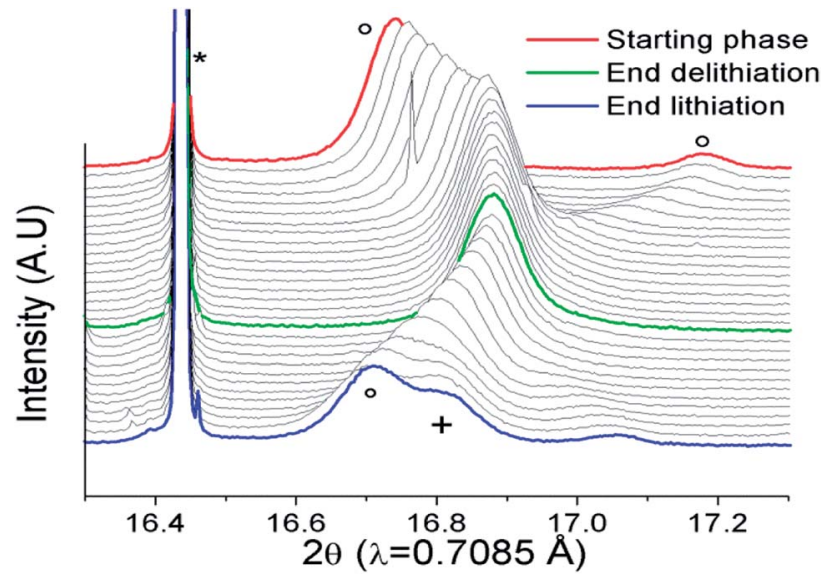

Fig. 8 Operando synchrotron XRD pattern of HE-NMC after 50 cycles in a "coffee bag" cell with pressure at $\mathrm{C} / 10$ between $2.5 \mathrm{~V}$ and $4.8 \mathrm{~V}$ vs. $\mathrm{Li}^{+} / \mathrm{Li}$. Titanium, NCM, and spinel are indexed by "*", "०", and "+", respectively.

cases, with and without pressure, leads to the same results. Subsequently, towards the end of the first charging step, the cell parameters reach constant values. During the first discharge, a reversal process is observed for the $a$ and $c$ lattice parameters, suggesting complete reversibility of the structural changes involved. Interestingly, the same study with the pressure inside the modified "coffee bag" cell shows entirely different behaviour, especially during the first lithiation process (Fig. 8).

It is well known from the literature that the HE-NMC presents monoclinic $\mathrm{Li}_{2} \mathrm{MnO}_{3}$-domains. As a result, all peaks at small angles are split in two during lithiation. One of these peaks is ascribable to the starting material, while the second one, is assigned to a manganese-spinel-type phase (Fig. 8, “+”)

These results prove the high importance of having pressure inside the cell when looking at electrochemical reactions using in situ techniques. With a classic design without any pressure, a part of the information about the reaction mechanism would be hidden.

To investigate the other effect of the pressure on the "coffee bag" cells, electrochemical impedance measurements (Fig. 9) were conducted for three different configurations of the "coffee bag" cells with titanium windows; (i) a "coffee bag" without any pressure, (ii) a "coffee bag" with an external pressure from rubber plate and (iii) a "coffee bag" cell with an external pressure from a rubber plate and a wave spring.

This new cell design offers the opportunity to measure electrochemical impedance and XRD or XAS at the same time due to the flexible design. In the following chapter, we want to stress the point about the effect of the spring on the reaction resistance.

Obviously, the magnitude of the pressure is (iii) $>$ (ii) $>$ (i). Fig. 10 shows the Nyquist plots of the impedance spectra of three different configurations of the "coffee bag" cells at $3.78 \mathrm{~V}$. The impedance spectra showed the distinct difference depending on the pressure. The result suggests the stronger pressure by the rubber plate and/or the wave spring makes the impedance smaller.

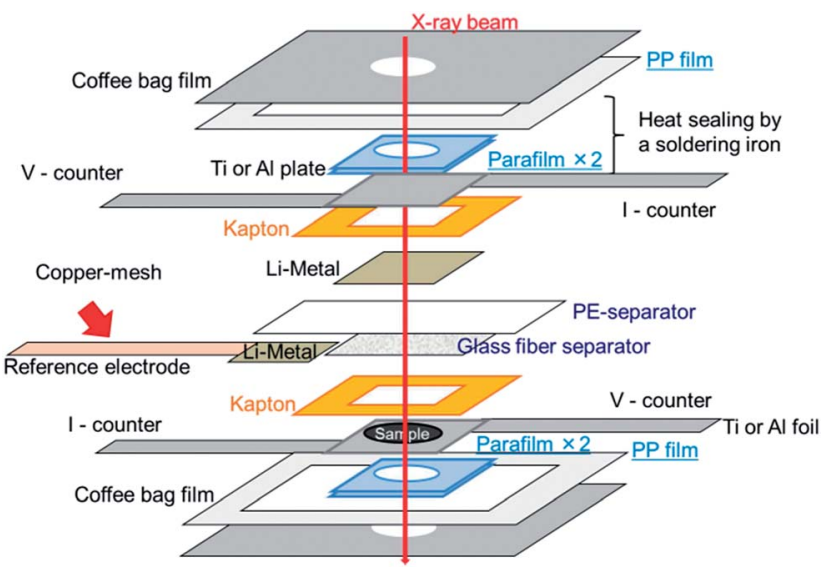

Fig. 9 Modified "coffee bag" cell design including reference electrode for impedance spectroscopy measurement.

For detailed investigation, equivalent circuit fitting was applied by using an equivalent circuit shown in Fig. 11. In the equivalent circuit, $R_{\mathrm{S}}$ is the electronic and ionic resistance, $R_{1}$ and CPE1 are the resistance and capacitance of the first semicircle, respectively, and $R_{2}$ and $C_{2}$ are the double-layer capacitance and charge-transfer resistance of the working electrode, respectively. The origin of the first semicircle is not clear, however it is reasonable to suppose that it comes from contact resistances between the active materials and the current collector of the working electrode.

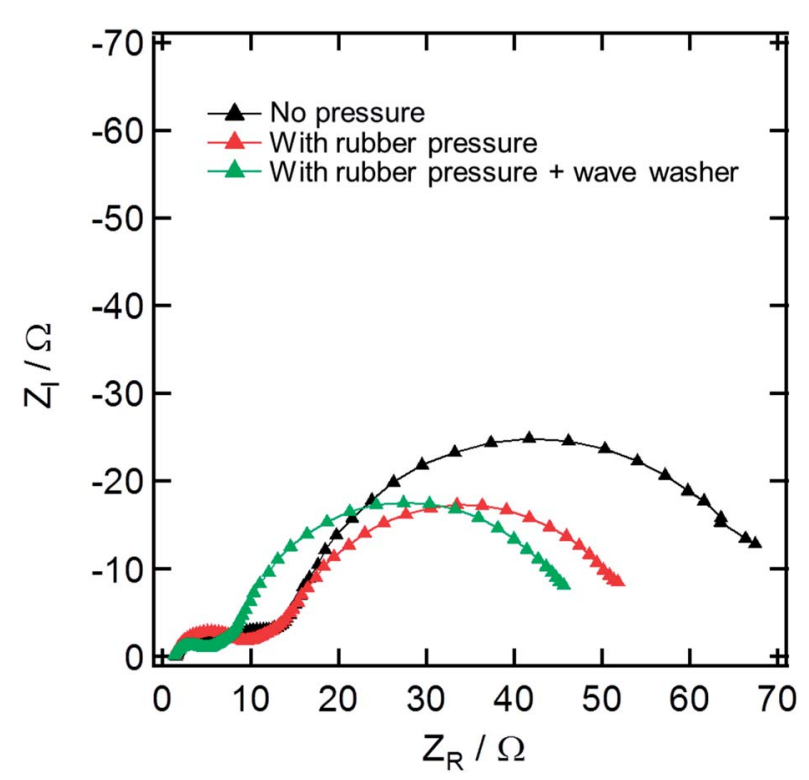

Fig. 10 Nyquist plots of the impedance spectra of three different configurations of the "coffee bag" cells at $3.78 \mathrm{~V}$.

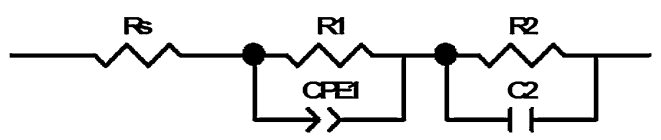

Fig. 11 Equivalent circuit used for the fitting. 

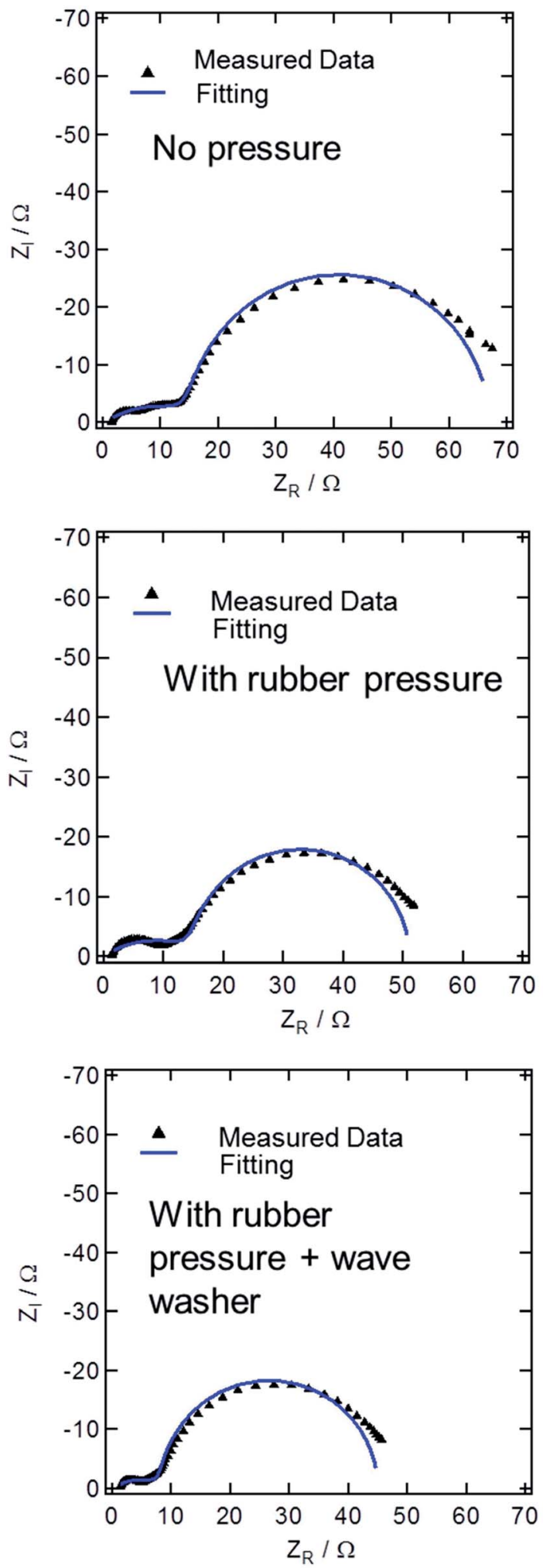

Fig. 12 Fitted spectra depending of the configuration.

Fig. 12 and 13 show the fitted spectra on the Nyquist plots and the variation of the estimated $R_{1}$ and $R_{2}$, respectively. The rubber pressure made charge-transfer resistance $R_{2}$ smaller mainly due to the suppression of the inhomogeneous reaction in the perpendicular direction to the current collector. The

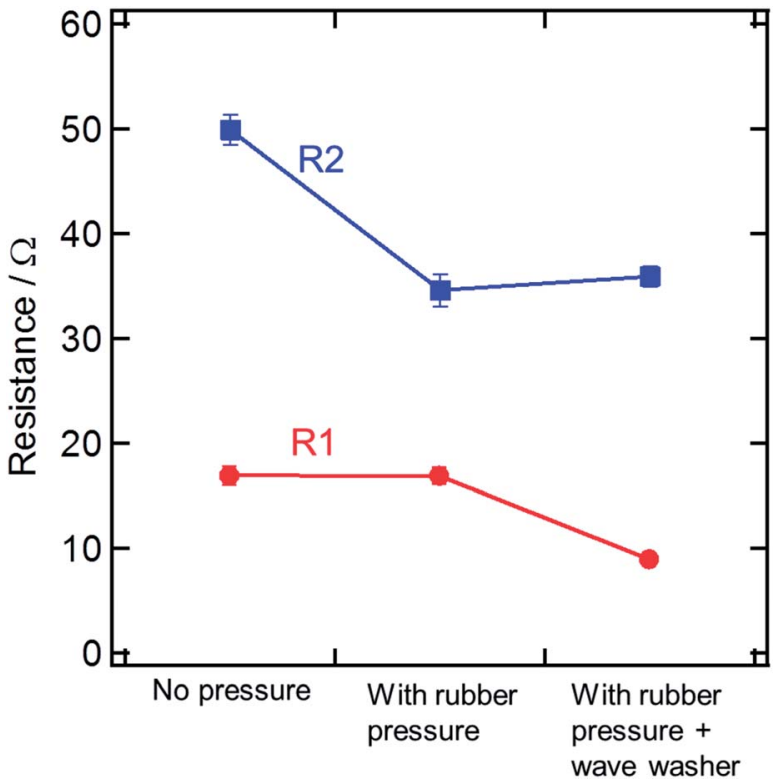

Fig. 13 Variation of the estimated $R_{1}$ and $R_{2}$.

additional pressure by the wave washer seemed to suppress the contact resistance of the working electrode.

This result suggested the lower resistance in the third configuration with the spring showing that the pressure applied on the "coffee bag" will enable fast operando measurements with high currents density.

\section{Conclusions}

In this study, we demonstrated a new way to apply pressure on "coffee bag" cells in order to obtain a very reliable measurement system, adaptable to all the in situ characterizations especially for long-term measurements. By replacing the Kapton windows (weak with risk of leakage) by titanium or aluminium, we are able (i) to avoid air and moisture exposure, (ii) to increase the lifetime of the "coffee bag" and (iii) to apply a pressure similar to the one we have in standard coin cell by using a wave spring compress on the new "hard" window. This modified "coffee bag" cell with pressure presents the same electrochemical results as those obtained in standard coin cells. With this new configuration we were able to investigate different materials and to identify a new process using operando XRD with HV-NMC material. The second attempt was done in order to modify the coffee bag cell and to develop in situ reliable cell for fast measurements. The first preliminary results showed the importance of using a spring similar to the one available in the real coin cell.

\section{Notes and references}

1 J. M. Tarascon and M. Armand, Nature, 2001, 414, 359-367. 2 J. Vetter, L. J. Hardwick, A. Wuersig, M. Holzapfel, O. D. Schneider, J. Ufheil and P. Novák, ECS Trans., 2007, 27, 29-43. 
3 M. Morcrette, Y. Chabre, G. Vaughan, G. Amatucci, J. B. Leriche, S. Patoux, C. Masquelier and J. M. Tarascon, Electrochim. Acta, 2002, 47, 3137-3149.

4 J. N. Reimers and J. R. Dahn, J. Electrochem. Soc., 1992, 139, 2091-2097.

5 I. A. Courtney and J. R. Dahn, J. Electrochem. Soc., 1997, 144, 2045-2052.

6 S. Mukerjee, T. R. Thurston, N. M. Jisrawi, X. Q. Yang, J. McBreen, M. L. Daroux and X. K. Xing, J. Electrochem. Soc., 1998, 145, 466-472.

7 J. C. Jumas, P. E. Lippens, J. Olivier Fourcade, A. Gheorghiu de La Rocque, C. Senemaud, M. Womes and I. F. Lefebvre, Rev. Metall./Cah. d'Inf. Tech., 1999, 96, 1067-1072.

$8 \mathrm{~J}$. McBreen and M. Balasubramanian, JOM, 2002, 54, 25-28. 9 A. Deb and E. J. Cairns, Fluid Phase Equilib., 2006, 241, 4-19. 10 P.-E. Lippens, M. Khalifi, M. Chamas, A. Perea, M.-T. Sougrati, C. Ionica-Bousquet, L. Aldon, J. OlivierFourcade and J.-C. Jumas, Hyperfine Interact., 2012, 206, $35-46$.
11 A. S. Andersson, B. Kalska, L. Haggstrom and J. O. Thomas, Solid State Ionics, 2000, 130, 41-52.

12 C. Villevieille, M. Boinet and L. Monconduit, Electrochem. Commun., 2010, 12, 1336.

13 K. J. Rhodes, R. Meisner, M. Kirkham, N. Dudney and C. Daniel, J. Electrochem. Soc., 2012, 159.

14 N. E. Leadbeater and J. R. Schmink, Nat. Protoc., 2008, 3, $1-7$.

15 J. T. Li, J. C. Fang, H. Su and S. G. Sun, Progr. Chem., 2011, 23, 349-356.

16 F. Rosciano, M. Holzapfel, H. Kaiser, W. Scheifele, P. Ruch, M. Hahn, R. Kötz and P. Novák, J. Synchrotron Radiat., 2007, 14, 487-491.

17 J. B. Leriche, S. Hamelet, J. Shu, M. Morcrette, C. Masquelier, G. Ouvrard, M. Zerrouki, P. Soudan, S. Belin, E. Elkaïm and F. Baudelet, J. Electrochem. Soc., 2010, 157, A606-A610.

18 N. Tran, L. Croguennec, M. Menetrier, F. Weill, P. Biensan, C. Jordy and C. Delmas, Chem. Mater., 2008, 20, 4815-4825. 